\title{
Utilization Waste of Cacao Skin Fermentation in The Feed to Increase Duck Egg Production
}

\author{
I Suryadi $^{1}$, R Novia $^{2}$, N Nilawati ${ }^{3}$ \\ Lecturer of the Agricultural Polytechnic Payakumbuh State, Indonesia ${ }^{1,2,3}$ \\ \{is_metsuryadi@yahoo.co.id ${ }^{1}$, nilanilawati70@yahoo.com ${ }^{3}$ \}
}

\begin{abstract}
The largest production cost in poultry farming is feed cost which is about $60-70 \%$, so it is necessary to find and utilize alternative feed ingredients that do not compete with human, the price is cheap, easy to get and do not ignore the nutrient content of the feed material. One of the agricultural waste that is available in large quantities and can be utilized as an alternative feed material is cocoa skin. Optimal use of cocoa leather as a concentrated material faces an obstacle in the form of low nutritional value, high coarse fiber, quickly damaged or rotten and not durable to be stored. To improve the value of the benefits of cocoa skin can be done with cacao waste skin fermentation. Fermentation cacao skin treatment that has been implemented here is to use urea and starbio with different comparisons. So it can be known as the right formula for optimal utilization for duck feed. This research has been conducted in the Laboratory and Cage Experiment State Polytechnic Payakumbuh State. The study was conducted in stages, consisting of 3 stages of research: A. Testing the effect of various comparisons of materials for fermentation formulations on cocoa skin B. Testing of fermented cocoa skin waste for grower ducks (year 1) C. Testing next to the early duck layer to see the production and quality of duck eggs (year 2). From this research, it was found that the second treatment of cocoa skin, starbio, and urea (100: 0,2: 0,4$)$ showed the best result for the initial production of laying duck and decrease of crude fiber content, the increase of protein and fat content.
\end{abstract}

Keywords: Cocoa skin fermentation, starbio, urea, duck

\section{Introduction}

\section{I.I Page Setup}

One of the West Sumatera commodity crops is cocoa/cocoa (Theobroma cacao). The parts of the cocoa plant are cacao fruits, seeds, and placenta.

Cocoa fruit skin is an agro-industrial waste produced by cocoa plants. The availability of cocoa fruit skin is quite large because about $75 \%$ of one whole fruit is how much fruit, while cocoa beans are $23 \%$ and $2 \%$ placenta [1]. In terms of the content of food substances cocoa fruit skin can be used as animal feed because it contains crude protein $11.71 \%$, crude fiber $20.79 \%$, fat $11.80 \%$ and BETN $34.90 \%$ [2].

The skin of a cocoa fruit is beneficial as the usual animal feed is given in the form in the form of a segment with the treatment dried and crushed. Cacao fruits have a production value 
that can be developed by farmers and many nutrient minerals, especially $\mathrm{K}$ and $\mathrm{N}$, fiber, fat and a number of organic acids that can be used for animal feed. Cocoa peel is always available throughout the year. Meanwhile, with the correct interval and cutting way from the forests of plantation crops are also always available to feed ingredients.

In addition, the limiting factor of giving the skin of cocoa fruit as animal feed is the existence of theobromine anti-nutrients on the skin of cocoa. Theobromin is a harmless alkaloid that can be destroyed by heating or drying, but continuous feeding of theobromin can reduce growth [3] Therefore, to maximize the use of cacao fruits good for livestock, it is necessary to improve the quality one of them by fermentation

Cocoa fruit skin contains theobromine alkaloid (3,7 - dimethylamine) which is a limiting factor in the use of cocoa waste as animal feed.

To increase the nutritional value and reduce theobromine content the usual use of fermentation. Fermentation is one of the technologies to increase the nutritional value of high fiber feed. Fermentation can hydrolyze protein, fat, cellulose, lignin and other polysaccharides, so the fermented material will have higher digestibility, fermentation will increase Total Digestible Nutrient (TDN)[4]. With the high protein so that the availability of nitrogen for microbial growth for the better. Nearly $80 \%$ of rumen microbes require nitrogen to synthesize their body proteins. Good microbial growth will cause the digestibility of the feed also becomes better. The content of lignin in the fruits of low fermented cocoa fruits is due to the fermentation treatment with urea able to loosen the ligniselulosa bond so it is more easily digested by rumen microbes.

The increase of protein through the fermentation process occurs because the work of the microbial mass during fermentation will break the complex molecules into simpler, more easily digestible molecules and microbial mass (the microbial body) that work itself is a source of protein so that the fermented protein becomes increased. Pro Protein of microbial origin is called the Single Cell Protein (PST)

The process of fermenting the nutritional value of cocoa fruit skin waste can be improved so it is feasible to feed the goat and cow reinforcement even for poultry rations (chickens and ducks).

A lot of research is done for kakao.kerco skin fermentation. The only requirement is a stater (microbe) and urea only. But not explained for the needs of raw materials (cocoa skin) is used. Because the comparative density of the ingredients involved in the fermentation process will produce the right composition and maximize its benefits for livestock.

Duck is one type of poultry that can offset the growth rate of animal protein needs because ducks have advantages among other local poultry (1). egg production is high (200-250 eggs per year), (2). does not incubate its eggs so effective in producing eggs, (3) relatively high egg prices compared to other poultry eggs and (4). (4) Duck production products such as feathers can be utilized as industrial materials such as cloth, soft brush, duster, mattress contents and so forth [5], [6].

The main benefit expected in raising ducks is eggs. One factor to consider for egg production is feed. Lack of nutrients in the growth period can lead to inhibition of adult genes become inhibited and egg production to fall. Conversely, if the quality of the food provided is good, then the adult gender will be achieved faster and egg production will be produced relatively higher. The feed has an important role in the duck breeding business because the quantity and quality of feed will affect the ability of livestock production.

The high cost of making livestock feed is due to the limited supply available in the market, which can be said to be less than the livestock needs in Indonesia. A limited supply of raw 
materials is due to the lack of productive agriculture. Also because of the increasingly narrow farmland.

High-quality rations at the moment are relatively expensive, for example, fish and soybean flour, and these ingredients are still imported from abroad. Meanwhile, domestic production is still not able to meet the needs of these materials.

In addition feed is the largest production cost of about $60-70 \%$ of the total production costs, so it is necessary to find and utilize other alternatives that do not compete with humans, the price is cheap, easy to get and do not ignore the nutritional content of the feed material. a potential alternative is the fruits of fermented cocoa

One way to improve cocoa skin quality is through fermentation and finding the right drying time. So obtained fermented cocoa skin that has high nutritional value and has a long hoop and applied directly n duck layer to see egg production.

\subsection{Special Purpose}

The final goal of this series of research is to find cheap, safe and environmentally friendly duck feed products as well as raw waste (fermented cocoa skin)

To achieve the final goal there are several stages of research conducted over two years, which is implemented gradually with the specific objectives of each are as follows:

Research Year I consists of 2 stages, namely:

1 Analysis of nutrient content on the use of strabio and urea with different ratios in cocoa skin fermentation.

Objective: To know the comparison between cocoa skin, starbio and urea in the fermentation process.

2 The results of the first year of this year, tested by storing power see rancidity, grow moldy and slimy mucus. The goal is to know how long this cocoa leather can be stored.

The second-year study consists of 1 stage, namely:

1. Aplikasin results of stage 1 on the maintenance of ducks with different percentages, which aim to see what percentage of the use of fermented cocoa skin is good and can still be tolerated in duck rations to increase duck egg production and reduce production costs.

\subsection{Research Benefits}

Cocoa leaf waste has been allowed to dry up beside the garden area and a small portion is processed simply. If not utilized properly will cause environmental pollution due to accumulation in the area around the land or community home.

In addition to utilizing the waste will also be beneficial for the farmers, as it will reduce feed costs, as it is known that the cost of feed-in livestock raising is $60-70 \%$ of the cost of production.

Increasing the production of duck is very dependent on food or rations were given by the farmer. The raw material to make animal feed is caused by the availability of available in the market is very limited in number, even can be said less than the needs of farms in Indonesia. A limited supply of raw materials is due to the lack of productive agriculture. Also because of the increasingly narrow farmland.

High-quality rations at the moment are relatively expensive, for example, fish and soybean flour, and these ingredients are still imported from abroad. Meanwhile, domestic production is still not able to meet the needs of these materials. 
To reduce the cost of production, it is necessary to find alternative ingredients one of these alternative substances is fermented cocoa skin. has the nutritional value needed by livestock. A good feed will ensure adequate availability of nutrients for the growth, production, and reproduction of a duck

Other effects of fermented cocoa leather making for duck feed are among others 1) Increased income for farmers or ranchers, due to increased egg production. 2) Operational cost savings of the Sanitation Department, 3) Environmental Sanitation, and 4). With the management of waste from the source of this is the land or house in the processing of cocoa skin then there is no need for any landfill that requires a large area of land and causes problems of pollution, landslide hazards, diseases, etc.

\section{Research Methods}

\section{I $\quad$ First Year}

Year 1 stage 1

Coconut Skin Canning according to Treatment

Selection of cocoa skin waste

(field survey)<smiles>C1=CC2CCC=C12</smiles>

Cacao skin sampling<smiles>C1=CC=C1</smiles>

Mad cocoa fruit shell cutter<smiles>C1CC2CCC2C1</smiles>

After chopping and sprinkle starbio and urea with comparison according to Treatment<smiles>C1=CC2CCC=C12</smiles>

Stir well with husk with bran<smiles>C1CC2CCC2C1</smiles>

Put the brown skin into a $5 \mathrm{~kg}$ plastic bag sealed tightly until it does not enter the air<smiles>C1CCC1</smiles>

Peram for 10-15 days for the fermentation process produced fermented cocoa skin<smiles>C1=CCC1</smiles>

Applied or saved for use when needed

\section{$2.2 \quad$ Aim}

Evaluation of the use of cocoa skin, starbio and urea with different amounts of comparison to cocoa skin in the fermentation process.

Knowing the resistance of the resulting fermented cocoa skin 


\subsection{Time and place}

This research was conducted by Farm and Laboratory of Agriculture State Polytechnic of Payakumbuh April 2017 until November 2017

\subsection{Material and Tools}

The leather of kajao, bran, laru tempe, steamer, plastic, blender chemicals for protein analysis and crude fiber

\subsection{Experimental design}

The study used a Completely Randomized Design with 4 treatments and 5 replications. Treatment is

$\mathrm{K} 1$ = Cacao skin $(\mathrm{kg})$ : starbio $(\mathrm{kg}):$ urea $(\mathrm{kg})=100: 0: 0$

$\mathrm{K} 2=$ Cacao skin $(\mathrm{kg})$ : starbio $(\mathrm{kg})$ : urea $(\mathrm{kg})=100: 0.2: 0.4$

$\mathrm{K} 3=$ Cocoa $(\mathrm{kg})$ : starbio $(\mathrm{kg})$ : urea $(\mathrm{kg})=100: 0.2: 0.6$

$\mathrm{K} 4$ = Cocoa $(\mathrm{kg})$ : starbio $(\mathrm{kg})$ : urea $(\mathrm{kg})=100: 0.2: 0.8$

\subsection{Parameter Observed}

Analisa Rough Fiber

Protein Analysis

Analyze Fat Rough

Year 1 Stage 2

Year two of this research is to know the best shelf-life (fermented cocoa skin) stored for 7 days, 14 days, 21 days against the rottenness and rancidity and the growing mucus/fungus

\subsection{Processing data}

The data obtained were analyzed statistically and continued with the DMRT test when there was a difference between treatments

\section{Expected Results And Outside}

\section{I Rough Fiber Content}

Table 1. Raw Content of Rough Cocoa Skin After Fermentation

\begin{tabular}{ll}
\hline Treatment & \% Crude fiber \\
\hline K1 (Kontrol) & $39.44^{\mathrm{a}}$ \\
\hline K2 & $28.26^{\mathrm{b}}$ \\
\hline K3 & $29.07^{\mathrm{b}}$ \\
\hline K4 & $28.88^{\mathrm{b}}$ \\
\hline
\end{tabular}

The number followed by the same letter states no significant difference at the 0.05 level. 
Judging from the nutritional content of cocoa peel skin, it can be said that the coarse fiber content of the fermented cocoa peel is getting more and more decreased when compared with the control. It is very important to note because crude fiber is very influential in livestock digestibility. The skin of fermented cocoa had a significant effect $(0.05>\mathrm{P})$ for each treatment compared with the control ie without treatment. This states that fermentation will cause the nutritional value of the skin for cocoa can be improved because the poultry feed is very good in poultry feed besides protein and metabolism energy, so as to meet the requirement of feed concentrate on livestock. Starbio in livestock feed as fermentor or Aspergillus niger, so in fermentation the benefits obtained include: can reduce the content of crude fiber and protein values of the skin of cocoa fruit will increase.

Starbio probiotic is an aerobic probiotic producing carbohydrate-breaking enzymes (cellulose, hemicellulose, lignin), protein and fat.

Probiotics starbio is a colony of microbial seedlings (derived from cow's stomach) packaged in a mixture of soil and grassroots and leaves or twigs are decomposed. In the colony there are several microbes that have special functions, such as Cellulomonasclostridium thermocellulosa (fat digesters), Agaricus and coprinus (lignin digesters), and Klebssiella and Azozpirillum trasiliensis (protein digesters).

In this research, fermentation can be seen from the following signs: if it is noticed that the surface of the cocoa bean slices is a dark brown color like tapae. And the failure of fermentation is marked with a slimy cocoa skin surface or there are orange spots and fishy smell.

One that determines the success of fermentation can be caused by the water content of the fermented material, which is about $60 \%$. It is in the opinion of Anonimus (2001) that the water content in the cocoa skin in the fermentation process to produce optimal yield is $60 \%$, the water content in fermentation process is very important because it serves to support the microbial life cycle in both an aerob and aerobic conditions. This is in the opinion [7] states that the fermentation process starts from the aerobic environment where the substances still contain oxygen, as soon as the oxygen is discharged then the aerobic process begins, at this very active stage are the bacteria that make up volatile organic acids. So if the anaerobic environment is met then organic acids will not evaporate so that the results of fermentation as expected and the results of crude fiber content decreased.

\subsection{Protein levels}

Table 2. Mean Protein Content of Cocoa Sugar Leaf Fermentation

\begin{tabular}{ll}
\hline Treatment & $\%$ Protein levels \\
\hline K1 (Kontrol) & $5.72^{\mathrm{a}}$ \\
\hline $\mathrm{K} 2$ & $9.40^{\mathrm{c}}$ \\
\hline $\mathrm{K} 3$ & $9.32^{\mathrm{c}}$ \\
\hline $\mathrm{K} 4$ & $8.94^{\mathrm{b}}$
\end{tabular}

The number followed by the same letter states no significant difference at the 0.05 level.

The skin of fermented cocoa had a significant effect $(0.05>\mathrm{P})$ for each treatment compared with the control ie without treatment. However, between the treatment of K2 and K3 visible effect is not real $(0.05<\mathrm{P})$. Compared with the control of fermented cocoa skin protein level is increased This is caused in the process of fermentation occurs bioconversion of compounds of organic and inorganic compounds into protein cells so that the increase in protein levels. 
The content of lignin in the fruits of low cacao fermented fruits is due to the fermentation treatment with urea able to loosen the lignocellulose bond to more easily digested by rumen microbes.

Rough proteins are complex organic compounds that have high molecular weights, such as carbohydrates and lipids. Proteins contain elements of carbon, hydrogen, and oxygen, but in addition, all proteins contain nitrogen.

Starbio serves to ferment high-fiber raw materials Starbio (microbial starter) is a brown powder feed supplement, composed of microbes derived from ruminant ruminants that are cultured in natural ingredients, such as soil, grassroots and dust have decomposed. Cocoa leather fermented with starbio can increase the protein content caused by the increase in microbial decomposers, which die because it can not survive in the acidic atmosphere. In this case, the bacteria decompose one of them is Saccharomyces spp which excretes extracellular enzymes (cellulose) that can decompose the cellulose carbon chain, so this water-insoluble compound becomes a simple soluble carbohydrate and can be absorbed by microorganisms.

\subsection{Fat content}

Table 3. Mean of fermented cocoa skin fat content

\begin{tabular}{ll}
\hline Treatment & $\%$ Fat content \\
\hline K1 (Kontrol) & $0,05^{\mathrm{a}}$ \\
\hline K2 & $0,09^{\mathrm{c}}$ \\
\hline K3 & $0,07^{\mathrm{b}}$ \\
\hline K4 & $0.07^{\mathrm{b}}$ \\
\hline
\end{tabular}

The number followed by the same letter states no significant difference at the 0.05 level.

The skin of fermented cocoa had a significant effect $(0.05>\mathrm{P})$ for each treatment compared with the control ie without treatment. However, between treatment $\mathrm{K} 3$ and $\mathrm{K} 4$ visible effect is not real $(0.05<\mathrm{P})$. Compared with skin fatty skin control fermentation is increased. Starbio probiotic is an aerobic probiotic producing carbohydrate-breaking enzymes (cellulose, hemicellulose, lignin), protein and fat.

Probiotics starbio is a colony of microbial seedlings (derived from cow's stomach) packaged in a mixture of soil and grassroots and leaves or twigs are decomposed. Colonies contain several microbes that have various functions, such as Cellulomonasclostridium hemicellulose (fat digesters), Agaricus and Coprinus (lignin digesters), and Klebsiella Azozpirillum trasiliensis (protein digesters).

\subsection{Storability}

Table 4. Mean Power Save Skin cocoa fermentation

\begin{tabular}{ll}
\hline Treatment & Endurance (Day) \\
\hline $\mathrm{K} 1$ (Kontrol) & $5^{\mathrm{a}}$ \\
\hline $\mathrm{K} 2$ & $14 \mathrm{~b}$ \\
\hline $\mathrm{K} 3$ & $15^{\mathrm{b}}$ \\
\hline
\end{tabular}




K4 $15^{\mathrm{b}}$

The number followed by the same letter states no significant difference at the 0.05 level.

To suppress the anti-nutritional effects and maximize the use of cocoa fruit skin and extend the shelf life it is necessary to do one of them by fermentation.

The skin of fermented cocoa had a significant effect $(0.05>\mathrm{P})$ for each treatment compared with the control ie without treatment.

Compared with fermented cocoa skins' storage power controls an increase of fermentation process succeeded in showing the following characteristics: the surface of cocoa fruit skin slices brownish or blackish, sweet-smelling like the smell of tape. Fermentation is considered a failure if the fermented product smells fishy or rotten, the skin is slimy, and there are yellow or orange spots on the surface of the cocoa peel. This is allegedly caused by cocoa skin water content is almost the same.

Cacao fruits can not be stored for a long time because the water content is high so easily rot and moldy, resulting in the skin of cocoa fruit is not palatabel for cattle.

Usually fermented foodstuffs have better nutrition and nutritional content than their origin, because microbes are catabolic or break down complex components into simpler substances that are easier to digest and microbes can also produce amino acids and some vitamins such as riboflavin, vitamin $\mathrm{B} 12$, provitamin $\mathrm{A}$, can produce the preferred flavors and can reduce toxins / anti-nutrients contained in the material.

\section{Conclusions}

1) There is a decrease in crude fiber and increased protein and fat fermented cocoa leather

2) The shelf life of fermented cacao skin can be up to 14 days

3) The best research results are: $\quad \mathrm{K} 2$ : Cocoa Leather $(\mathrm{kg})$ : starbio $(\mathrm{kg})$ : urea $(\mathrm{kg})=100$ : $0.2: 0.4$

\section{References}

[1] W. S, Cultivation of Cocoa Crops. Bandung: Angkasa, 2008.

[2] Nuraini, "Isolasi Kapang Karotenogenikuntuk Memproduksi Pakan Kaya BKaroten," Padang, 2007.

[3] N. Nuraini, Y. S. Nur, and A. Djulardi, "Cocoa Pods with Different Nitrogen Sources Fermented by Using Pleurotus ostreatus as Poultry Feed," Int. J. Poult. Sci., vol. 18, no. 7, pp. 328-333, Jun. 2019.

[4] Anggorodi, Ilmu Makanan Ternak Umum. Jakarta: PT Gramedia, 1979.

[5] M. Rasyaf, Seputar Makanan Ayam Kampung. Yogyakarta: Kanisus, 1992.

[6] B. Srigandono, Ilmu Unggas Air. Yogyakarta: Universitas Gadjah Mada, 1986.

[7] A. and A. M. Wahyudi, "Development of Fermented Starter Production of Bio Gas with Fibrocytic Isolate Isolate of Rumen and Sheep's (Production Efficiency of Methane Gas as Alternative Energy Source).," University of Muhammadiyah Malang, 2006. 